\title{
The Effect of Current Ratio, Return on Assets, Total Asset Turnover and Sales Growth on Capital Structure in Manufacturing Company
}

\author{
Mohd. Nawi Purba ${ }^{1}$, Erika Kristiany Br. Sinurat ${ }^{2}$, Ahmad Djailani $^{3}$, Winda Farera ${ }^{4}$
}

1,2,3,4 Faculty of Economics, University of Prima Indonesia, Medan, Indonesia

\section{A R T I C L E I N F O \\ Article history: \\ Received 13 July 2020 \\ Received in revised form \\ 10 July 2020 \\ Accepted 28 July 2020 \\ Available online 29 August \\ 2020}

Keywords:

Capital Structure, Current

Ratio, Return on Assets,

Sales Growth Total Asset

Turnover

\section{A B S T R A C T}

This study aimed to determine how much effect the Current Ratio, Return on Assets, Total Asset Turnover and Sales Growth have on the Capital Structure of manufacturing companies listed on the IDX from 2016 to 2018. The research method used was descriptive method and multiple linear analysis method. The population of this study was 144 companies with a sample of these companies, namely 73 . The data used were financial reports published by the Indonesia Stock Exchange through the website www.idx.co.id. The variables related to this research are the Current Ratio, Return on Assets, Total Asset Turnover, and Sales Growth. The results showed that partially Current Ratio has a negative and significant effect on Capital Structure, Return on Asset did not have a significant effect on Capital Structure, and Total Asset Turn Over has no significant effect on Capital Structure, and Sales Growth has no significant effect on Capital Structure in manufacturing companies listed on the Indonesia Stock Exchange. Simultaneously Current Ratio, Return on Asset, Total Asset Turn Over and Sales Growth together have a significant effect on the capital structure of companies listed on the Indonesia Stock Exchange.

Copyright (C) Universitas Pendidikan Ganesha. All rights reserved.

*Corresponding author.

E-mail addresses: purbanawih67@gmail.com¹ (Mohd. Nawi Purba), sinuraterik77@gmail.com² (Erika Kristiany Br. Sinurat),

djailiahmad26@gmail.com³ (Ahmad Djailani),windaimoet87@gmail.com4 (Winda Farera) 


\section{Introduction}

In today's increasingly global economic conditions, it can be seen that competition between companies is getting tighter, making companies increasingly trying to maintain the survival of the company. The company's goal is to get maximum profit so that it is able to improve the welfare of shareholders, thereby increasing company value. In order to support the company's performance, very strong supporting factors are needed, especially in the field of funding. Funding can come from internal or external. So it can be said that the capital structure is one of the most fundamental problems in a company.

Capital Structure is a company action to fund its total assets where the decisions to be made pose challenges for the company (Claude, 2016) in (Mahirun \& Kushermanto, 2018). According to (Kesuma \& Gunadi, 2015) Capital Structure shows the level of ability to use the company's capital itself in fulfilling its obligations. According to (Dewi \& Suaryana, 2013) Capital Structure is the ratio between the amount of debt the company has and the total capital itself. According to Siti journal (Siregar, 2018), Capital Structure is a comparison of the amount of permanent short-term debt, long-term debt, and preferred stock and common stock. Therefore, the capital structure must be managed optimally. If it is not managed properly it will cause financial difficulties for the company. Therefore, financial managers have an important role in decision making so that the decision-making process can be more efficient Keown in (Riyanti \& Darto, 2019). One of the factors that influence the Capital Structure is the Current Ratio.

The Current Ratio owned by the company is a factor that affects the capital structure because high liquidity is able to reduce the use of external funds due to high internal funding. According to (Hery, 2016), Current Ratio is a description of how much the amount of current assets owned by the company is compared to the amount of current liabilities that will be due. According to (Fahmi, 2015), Current Ratio is a general measure used for short-term solutions and a company's ability to meet debt when it becomes due. According to (Supardi et al., 2016) Current Ratio is the company's performance in paying off its obligations at maturity. A high current ratio makes investors more interested in buying shares so that they can increase the company's stock price (Lilie et al., 2019; Setia Rini et al., 2018). Current Ratio is useful for assessing the company's ability to fulfill its obligations so that it can attract investors to invest.

Companies that have high profitability will make investors see the company's performance by how much return is received for each invested capital. According to (Pradana \& Kiswanto, 2013), Sales Growth is the company's performance to gain profits after determining a sales target. According to (Widhiari \& Aryani Merkusiwati, 2015) Sales Growth is a prediction of the company's future sales growth by looking at the successful behavior of investments in the previous period. Sales growth is used as a prediction for future growth. As long as the level of debt can increase profit growth, it is expected that the turnover of assets owned by the company and sales growth will also increase. But the existence of very high debt can increase the risk of the company's smooth running in short-term debt financing. So, it is expected that the company can maintain sales growth so that it can meet the survival of the company. To measure how far the effectiveness of a company is in managing its assets to generate sales; Return on Assets is carried out.

Return on Asset is the calculation of the benefits obtained by utilizing the use of company assets (Chandra et al., 2019). According to (Wijayanto, 2010) Return on Asset is a ratio used to measure how much profitability is generated from the use of company assets. According to (Murhadi, 2015) Return on Asset is a description of how much return is obtained for each invested in assets. According to (Haryanto, 2016), if the company has a high level of profitability, it shows that the company can generate enormous profits because it utilizes its assets. According to (Watiningsih, 2018), if the profitability in the company is high enough, the company's capital structure will be low so that the company uses smaller debt because it is able to provide sufficient funds through retained earnings.

According to (Akhtar et al., 2011) if the value of return on assets in the company is high, it indicates higher profitability

The following table of phenomena shows Current Assets, Net Profit, Total Assets, Sales and Total Debt of several manufacturing companies listed on the IDX 2016 - 2018. 
Table 1. Current Assets, Net Profit, Total Assets, Sales and Total Debt of several manufacturing companies listed on the IDX $2016-2018$

\begin{tabular}{lllllll}
$\begin{array}{llll}\text { ISSUERS } \\
\text { CODE }\end{array}$ & YEAR & $\begin{array}{l}\text { CURRENT } \\
\text { ASSETS }\end{array}$ & NET PROFIT & TOTAL ASSETS & SALES & TOTAL DEBT \\
\hline \multirow{2}{*}{ KDSI } & 2016 & $709,583,883,699$ & $47,127,349,067$ & $1,142,273,020,550$ & $1,995,337,146,834$ & $722,488,734,446$ \\
& 2017 & $841,180,577,983$ & $68,965,208,549$ & $1,328,291,727,616$ & $2,245,519,457,754$ & $842,752,226,507$ \\
& 2018 & $824,176,454,137$ & $76,761,902,211$ & $1,391,416,464,512$ & $2,327,951,625,610$ & $836,245,435,111$ \\
\multirow{3}{*}{ BATA } & 2016 & $533,900,133,000$ & $42,231,663,000$ & $804,742,917,000$ & $999,802,379,000$ & $247,587,638,000$ \\
& 2017 & $567,954,415,000$ & $53,654,376,000$ & $855,691,231,000$ & $974,536,083,000$ & $276,382,503,000$ \\
& 2018 & $569,545,551,000$ & $67,944,867,000$ & $876,856,225,000$ & $992,696,071,000$ & $240,048,866,000$ \\
\multirow{2}{*}{ KINO } & 2016 & $1,876,157,549,127$ & $181,110,153,810$ & $3,284,504,424,358$ & $3,493,028,761,680$ & $1,332,431,950,729$ \\
& 2017 & $1,795,404,979,854$ & $109,696,001,798$ & $3,237,595,219,274$ & $3,160,637,269,263$ & $1,182,424,339,165$ \\
& 2018 & $1,975,979,249,304$ & $150,116,045,042$ & $3,592,164,205,408$ & $3,611,694,059,699$ & $1,405,264,079,012$ \\
\hline
\end{tabular}

From the data obtained through the website www.idx.co.id regarding current assets, net profits, sales, and debt to manufacturing companies on the Indonesian stock exchange for the period 2016-2018, it can be seen that a phenomenon that occurs in current assets at PT Kedawung Setia Industrial Tbk (KDSI) experienced a decline from 2017 to 2018 of $2.02 \%$, but followed by a decrease in debt from 2017 to 2018 of $0.77 \%$. The net profit at PT Sepatu Bata Tbk (BATA) has increased from 2016 to 2017 by $27.05 \%$ but followed by an increase in debt from 2016 to 2017 of $11.63 \%$. For total assets at PT Kino Indonesia Tbk (KINO) has increased from 2017 to 2018 by 10.95\%, but followed by an increase in debt from 2017 to 2018 of $18.85 \%$. Sales at PT Kino Indonesia Tbk (KINO) decreased from 2016 to 2017 by $9.52 \%$, but followed by a decrease in debt from 2016 to 2017 of $11.26 \%$.

Based on this description, a research objective was formulated to analyze the Current Ratio, Return on Assets, Total Asset Turnover, Sales Growth to Capital Structure in manufacturing companies listed on the IDX for the period 2016 - 2018"

\section{Methods}

This study was a quantitative descriptive research. The sample used in this study was the financial data of companies listed on the IDX in 2016-2018. The sampling technique used was purposive sampling method.

The population in this study was 144 companies listed on the IDX for the period 2016 - 2018 with a sample size of 219 financial reports taken from 73 manufacturing companies listed on the IDX for the 2016 - 2018 period.

The data collection technique used in this study was using data from official companies that published their financial reports on the Indonesia Stock Exchange website, as well as review journals, books and papers to obtain a comprehensive theoretical basis.

\section{Normality test}

This test aimed to determine whether the residual variable is functioning normally or not in a normal distribution, where the techniques used are graphic analysis or statistical analysis (Ghozali, 2018).

\section{Multicollinearity Test} 2018).

This test was used to find a correlation or intercorrelation between independent variables (Ghozali,

\section{Autocorrelation Test} 2018).

This test was carried out to test for errors or not that result in correlation to the data (Ghozali,

\section{Heteroscedasticity Test}

This test was used to test for the similarity or inequality of variants and residuals of observations to other observations (Ghozali, 2018). 


\section{Multiple Linear Regression Test}

Multiple linear regression is useful for knowing the relationship between variable $\mathrm{X}$ and variable $\mathrm{Y}$. To determine the effect of independent variables and dependent variables, the data analysis model of this study used the following formula:

Information:

$$
\mathrm{Y}=\mathrm{a}+\mathrm{b} 1 \mathrm{X} 1+\mathrm{b} 2 \mathrm{X} 2+\mathrm{b} 3 \mathrm{X} 3+\mathrm{b} 4 \mathrm{X} 4+\mathrm{e}
$$

$\mathrm{Y}=$ Capital Structure

$\mathrm{a}=$ Constant

b1, b2, b3 b4 = State of Regression

$\mathrm{X} 1=$ Variable Current Ratio

$\mathrm{X} 2=$ Variable Return on Asset

$\mathrm{X} 3=$ Total Asset Turn Over variable

X4 = Sales Growth Variable

$\mathrm{e}=$ Estimated Error (0.05)

\section{Hypothesis testing}

The $t$ statistical test was used to prove whether the independent variable has an effect on the dependent variable individually (Ghozali, 2018). The t-test criteria are:

a. If $\mathrm{t}$-table $<\mathrm{t}$-count $<\mathrm{t}$-table, then Ho is accepted.

b. If $\mathrm{t}$-count $>\mathrm{t}$-table or $\mathrm{t}$-count $<\mathrm{t}$-table, then Ho is rejected.

The f statistical test was used to measure whether the independent variables as a whole have an effect on the dependent variable (Ghozali, 2018). The F test criteria are:

a. If F-count $<\mathrm{F}$-table, then Ho is accepted.

b. If F-count > F-table, then Ho is rejected.

The coefficient of determination was used to regulate how capable the model is to explain the variation of the independent variables (Ghozali, 2018).

\section{Results and Discussions}

\section{Results}

Descriptive Statistics of Data

In this study, descriptive statistical testing was to provide a description of data that explained the maximum value, minimum value, average value, and standard deviation used in the study.

Table 2. Descriptive Statistics Descriptive Statistics

\begin{tabular}{lccccc}
\hline & N & Minimum & Maximum & Mean & Std. Deviation \\
\hline CR & 173 & -0.43 & 1.78 & 0.6817 & 0.51459 \\
ROA & 173 & -8.33 & -1.61 & -3.3127 & 1.20555 \\
TATO & 173 & -6.47 & 0.7 & -0.1842 & 0.65991 \\
Per Penjualan & 173 & -6.01 & -0.63 & -2.4096 & 0.75508 \\
DER & 173 & -2.37 & 1.43 & -0.4402 & 0.78454 \\
\hline
\end{tabular}

Table 2 above shows the following results: 1) The current ratio variable has a total sample size of 173, with a minimum value of -0.43 , namely PT. Nusantara Inti Corpora Tbk in 2016 and the maximum value is 1.78, namely PT. Wismilak Inti Makmur Tbk in 2018. 2) The variable return on assets has a total sample size of 173, with a minimum value of -8.33, namely PT. Asahimas Flat Glass Tbk in 2018 and the maximum value is -1.61 , namely PT. Sido Muncul Tbk Herbal and Pharmaceutical Industry in 2018. 3) The total asset turnover variable has a total sample size of 173 , with a minimum value of -6.47 , namely PT. Malindo Feedmill Tbk in 2018 and a maximum value of 0.7, namely PT. Charoen Pokphand Indonesia Tbk in 2017. 4) The sales growth variable has a sample size of 173 , with a minimum value of -6.01 , namely PT. Nusantara Inti Corpora Tbk in 2018 and the maximum value is -0.63 , namely PT. Intan Wijaya International Tbk in 2017. And 5) The variable debt to equity ratio has a total sample of 173, with a minimum value of -2.37, namely PT. Kabelindo Murni Tbk in 2018 and a maximum value of 1.43, namely PT. Indal Aluminum Industry Tbk in 2016. 


\section{Normality test}

This test was conducted to determine the regression model and the residuals which have a normal distribution.

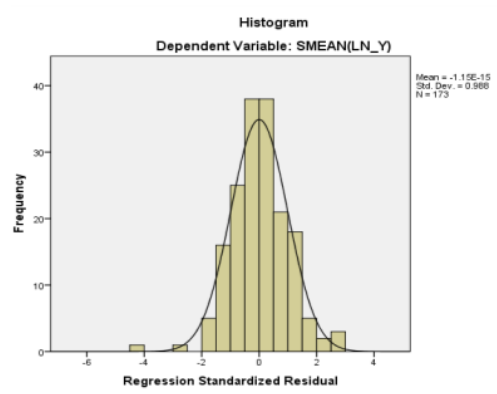

Figure 1. Histogram Normality Test

Based on Figure 1 above, it shows that the curve graph is an inverted bell where it is concluded that the residual data is normally distributed. Graph of Normality P - P Plot in Figure 2 below, it can be seen that the dots spread out close to the diagonal line. It can be concluded that the data are normally distributed.

Likewise, the results of the normal probability plot test are as follows

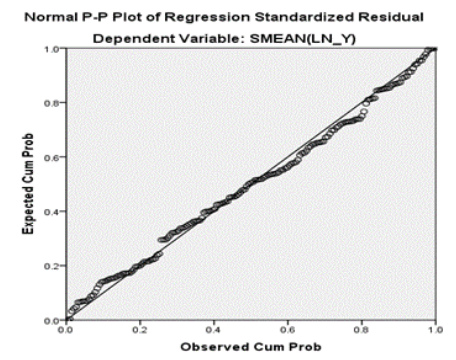

Figure 2. P - P Plot Normality Test

In addition to the analysis of histogram charts and the P - P Plot, it can be seen that the data is normally distributed or not, namely by using the Kolmogrov - Smirnov non-parametric statistical test, if the value is Asymp. Sig (2-tailed)> 0.05, then the data can be said to be normally distributed.

Table 3. Kolmogrov - Smirnov test

\begin{tabular}{llc}
\hline & & Unstandardized Residual \\
\hline $\mathrm{N}$ & & 173 \\
Normal Parameters ${ }^{\mathrm{a}, \mathrm{b}}$ & Mean & 0 \\
& Std. Deviation & 0.54740137 \\
& Absolute & 0.056 \\
Most Extreme Differences & Positive & 0.056 \\
& Negative & -0.044 \\
Test Statistic & & 0.056 \\
Asymp. Sig. (2-tailed) & & .200 \\
\hline
\end{tabular}

Based on Table 3 above, it can be seen that normality testing using the Kolmogrov - Smirnov statistic has a sig value of $0.200>0.05$ so that the data were normally distributed.

\section{Multicollinearity Test}

The multicollinearity test aimed to measure whether the regression model found a correlation between independent variables by looking at the Tolerance value or the Variance Inflation Factor (VIF) value. 
Table 4. Multicollinearity Test

\begin{tabular}{llcc}
\hline \multirow{2}{*}{ Model } & & \multicolumn{2}{c}{ Collinearity Statistics } \\
\cline { 3 - 4 } & & Tolerance & VIF \\
\hline \multirow{3}{*}{1} & CR & 0.833 & 1.2 \\
& ROA & 0.743 & 1.347 \\
& TATO & 0.887 & 1.128 \\
\hline & Per Penjualan & 0.934 & 1.07 \\
\hline
\end{tabular}

\section{Dependent Variable: DER}

Based on Table 4 above, it is shown that the tolerance value of the current ratio variable (0.833), return on assets $(0.743)$, total asset turnover $(0.887)$, and sales turnover $(0.934)$ is above 0.10 while the VIF value of the current ratio variable (1.2) ), return on assets $(1,347)$, total asset turnover $(1,128)$ and sales turnover (1.07) are below 10. Where the tolerance value limit is $>0.1$ and VIF $<10$, then in this regression model there is no multicollinearity between the independent variables.

\section{Autocorrelation Test} to the data.

The autocorrelation test aimed to test whether or not there was an error that results in correlation

Table 5. Autocorrelation Test

\begin{tabular}{cc}
\hline Run Test & Unstandardized Residual \\
\hline Test Value & 0.00603 \\
Cases $<$ Test Value & 86 \\
Cases $>=$ Test Value & 87 \\
Total Cases & 173 \\
Number of Runs & 79 \\
Z & -1.296 \\
Asymp. Sig. (2-tailed) & 0.195 \\
\hline
\end{tabular}

Data source: Results of SPSS 2020 data processing

Based on Table 5 above, it can be concluded that the value of Asymp. Sig. (2-tailed) of 0.195>0.05, the data is free from autocorrelation symptoms.

\section{Heteroscedasticity Test}

Heteroscedasticity test was used to test for the similarity or inequality of variants and residuals from observations to other observations.

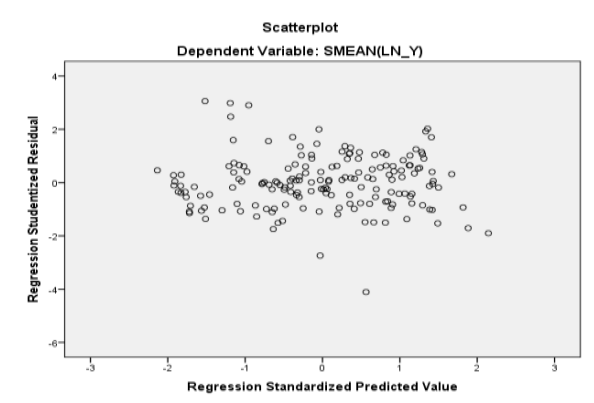

Figure 3. Scatterplot of Heteroscedasticity Test

Based on Figure 3 above shows the scatterplot, it can be seen that the dots spread randomly either above or below or around the zero $(0)$ on the Y axis, so from the graph it can be concluded that there is no heteroscedasticity in this test and is feasible to use. 
Table 6. White Test Results

\begin{tabular}{ccccc}
\hline Model & R & R Square & Adjusted R Square & $\begin{array}{c}\text { Std. Error of the } \\
\text { Estimate }\end{array}$ \\
\hline 1 & $.176^{\mathrm{a}}$ & 0.031 & 0.008 & 0.57499 \\
\hline & & & Data source: Results of SPSS 2020 data processing
\end{tabular}

Based on Table 6 above, it shows that the R Square value is 0.031 , then the calculated c2 value is: The formula $=\mathrm{n} x$ the value of $\mathrm{R}$ Square

$=173 \times 0.031$

$=5.363$ (calculated $c 2$ value)

While the $c 2$ table value of 7,815 is obtained from $\mathrm{k}-1(4-1=3)$ with a significance value of $5 \%$, it can be concluded that the value of $c 2$ count $<$ c2 table $(5,363<7,815)$, so there are no symptoms of heteroscedasticity.

\section{Results of Research Data Analysis}

Multiple Linear Regression Analysis

Y.

Multiple linear regression analysis was used to determine the relationship between variable $\mathrm{X}$ and

Table 7. Regression Equations

Coefficients $^{\mathrm{a}}$

\begin{tabular}{llccccc}
\hline \multirow{2}{*}{ Model } & \multicolumn{2}{c}{ Unstandardized } & \multicolumn{2}{c}{$\begin{array}{c}\text { Standardized } \\
\text { Coefficients }\end{array}$} & \multirow{2}{*}{ t } & Sig. \\
\cline { 2 - 4 } & \multicolumn{2}{c}{ Coefficients } & Std. Error & Beta & & \\
\hline \multirow{2}{*}{ (Constant) } & 0.556 & 0.209 & & 2.656 & 0.009 \\
& CR & -1.108 & 0.09 & -0.727 & -12.32 & 0 \\
& ROA & -0.013 & 0.041 & -0.02 & -0.314 & 0.754 \\
& TATO & 0.053 & 0.068 & 0.045 & 0.787 & 0.433 \\
& Per & 0.114 & 0.058 & 0.109 & 1.962 & 0.051 \\
\hline
\end{tabular}

Data source: Results of SPSS 2020 data processing

Based on Table 7 above, the regression formula is obtained as follows:

DER $($ Capital Structure $)=0.556-1.108$ CR -0.013 ROA +0.053 TATTOOS +0.114 Per Sale

\section{Coefficient of Determination}

The coefficient of determination was used to determine the effect of the model's ability to explain the variation of the independent variables.

Table 8. Test of the coefficient of determination

Model Summary

\begin{tabular}{ccccc}
\hline Model & R & R Square & Adjusted R Square & $\begin{array}{c}\text { Std. Error of the } \\
\text { Estimate }\end{array}$ \\
\hline 1 & $.716^{\mathrm{a}}$ & 0.513 & 0.502 & 0.55388 \\
\hline & & Data source: Results of SPSS 2020 data processing \\
& & Predictors: (Constant), X4, X3, X2, X1
\end{tabular}

Based on Table 8 above, it shows the results of the determination coefficient test, the value of the Adjusted R Square coefficient of determination is 0.502 , which means that $50.2 \%$ can be explained that the independent variable affects the capital structure while the remaining $49.8 \%$ is explained by other independent variables that are not careful in this study.

\section{Simultaneous Hypothesis Testing (Test F)}

The $\mathrm{F}$ test was used to prove whether the independent variable has an overall effect on the dependent variable. 
Table 9. F Test Results

ANOVA $^{\mathrm{a}}$

\begin{tabular}{llccccc}
\hline Model & $\begin{array}{c}\text { Sum of } \\
\text { Squares }\end{array}$ & df & Mean Square & F & Sig. \\
\hline \multirow{2}{*}{1} & Regression & 54.328 & 4 & 13.582 & 44.272 & $.000^{\mathrm{b}}$ \\
& Residual & 51.539 & 168 & 0.307 & & \\
\hline & Total & 105.868 & 172 & & Data source: Results of SPSS 2020 data processing
\end{tabular}

From table 9 above, it can be seen that the Fcount value is 44,272 and the Ftable value is significant at 0.05 and seen the df1 and df2 with the formula df1 $=\mathrm{k}-1=(4+1)-1=4, \mathrm{df} 2=\mathrm{n}-\mathrm{k}=173-5=168$ is 2.43 , then Fcoun $t>$ Ftable $(44.272>2.43)$ so that the results of the study reject Ho and accept Ha and the significant value is less than $0.05(0.000<0.05)$. Thus it can be concluded that the variables CR, ROA, TATO, and Sales Growth together have a significant effect on the Capital Structure of manufacturing companies listed on the IDX for the period 2016 - 2018.

\section{Partial Hypothesis Testing (Test - $t$ )}

The $t$ test was used to prove whether the independent variable affected the dependent variable individually. Based on the results of data processing with the SPSS program, the results of the $t$ test are as follows.

Table 10. Test Results - $t$

Coefficients $^{\mathbf{a}}$

\begin{tabular}{llccccc}
\hline \multirow{2}{*}{ Model } & \multicolumn{2}{c}{$\begin{array}{c}\text { Unstandardized } \\
\text { Coefficients }\end{array}$} & $\begin{array}{c}\text { Standardized } \\
\text { Coefficients }\end{array}$ & \multirow{2}{*}{ t } & Sig. \\
\cline { 2 - 4 } & B & Std. Error & Beta & & \\
\hline \multirow{2}{*}{ (Constant) } & 0.556 & 0.209 & & 2.656 & 0.009 \\
& CR & -1.108 & 0.09 & -0.727 & -12.32 & 0 \\
1 & ROA & -0.013 & 0.041 & -0.02 & -0.314 & 0.754 \\
& TATO & 0.053 & 0.068 & 0.045 & 0.787 & 0.433 \\
& Per & 0.114 & 0.058 & 0.109 & 1.962 & 0.051 \\
\hline
\end{tabular}

Data source: Results of SPSS 2020 data processing

\section{Discussion}

\section{The Effect of Current Ratio on Capital Structure}

From the partial test results, it can be seen that the CR variable has a t-count value of 12.32 with a ttable of $t \mathrm{df}=173$, and a $\mathrm{t}$-table of 1.97419 is obtained. Then tcount $>$ ttable $(12.32>1.97419)$ with a significant value of $0.000<0.05$. This shows that CR partially has a negative and significant effect on DER. The current ratio owned by the company is a factor that affects the capital structure because high liquidity is able to reduce the use of external funds due to high internal funding. According to (Hery, 2016) Current Ratio is a description of how much the amount of current assets owned by the company is compared to the amount of current liabilities that will be due. According to (Fahmi, 2015), Current Ratio is a general measure used for short-term solutions and a company's ability to meet debt when it becomes due. According to (Supardi et al., 2016) Current Ratio is the company's performance in paying off its obligations at maturity. A high current ratio makes investors more interested in buying shares so that they can increase the company's stock price (Lilie et al., 2019; Setia Rini et al., 2018). Current Ratio is useful for assessing the company's ability to fulfill its obligations so that it can attract investors to invest.

According to Herlambang \& Marwoto in the journal (Tanri et al., 2020) said that if the company has the ability to pay its current debt well, the company is in a liquid condition, but on the other hand, a company that is unable to pay it will be a liquid company. According to (Juliantika \& Dewi, 2016), according to the pecking order theory, companies that have high liquidity tend to use internal funds, so that the level of corporate debt will decrease due to the repayment of current debts.

The results of this study were in line with the results of research (Deviani \& Sudjarni, 2018) which stated that the current ratio partially has a negative effect on capital structure. In addition, there are the results of research conducted by (Juliantika \& Dewi, 2016) which stated that liquidity, which is proxied by the Current Ratio (CR), has a negative and significant effect on capital structure (DER). (Watung, 2016) 
stated that there is a negative influence between liquidity (current ratio) on capital structure. In addition, (Lasut et al., 2018). From the results of the $t$ test it is concluded that liquidity has a negative and significant effect on capital structure.

\section{The Effect of Return on Asset on Capital Structure}

From the partial test results, it can be seen that the ROA variable has a t-count of -0.314 with a ttable of $\mathrm{t} d f=173$, the $t$ table is 1.97419 . Then tcount $<$ ttable $(0.314<1.97419)$ with a significant value of $0.754>0.05$. This shows that ROA partially does not have a significant effect on DER in-manufacturing companies listed on the Indonesia Stock Exchange (BEI) for the period 2016 - 2018.

Return on Asset is the calculation of the benefits obtained by utilizing the use of company assets (Chandra et al., 2019). According to (Wijayanto, 2010) Return on Asset is a ratio used to measure how much profitability is generated from the use of company assets. According to (Murhadi, 2015) Return on Asset is a description of how much return is obtained for each invested in assets. According to (Haryanto, 2016), if the company has a high level of profitability, it shows that the company can generate enormous profits because it utilizes its assets. According to (Watiningsih, 2018), if the profitability in the company is high enough, the company's capital structure will be low so that the company uses smaller debt because it is able to provide sufficient funds through retained earnings. According to (Akhtar et al., 2011) if the value of Return on Assets in the company is high, it indicates higher profitability. The effect of liquidity on capital structure means that if the company's liquidity increases, the company's capital structure will decrease. It can be said that changes in profitability will not affect changes in capital structure.

This study was in line with the results of research (Naibaho et al., 2015) which stated that changes in profitability will not affect the capital structure. (Premawati \& Darma, 2019) also stated that there is a negative effect company size on capital structure. Research conducted (Prihasti, 2018) stated managerial ownership has no effect on capital structure.

\section{Effect of Total Asset Turnover on Capital Structure}

From the partial test results, it can be seen that the TATO variable has a t-count value of 0.787 with a t-table of $\mathrm{t} d \mathrm{f}=173$, and the $\mathrm{t}$-table is 1.97419 . Then tcount $<$ ttable $(0.787<1.97419)$ with a significant value of $0.433>0.05$. This shows that partially TATO has no significant effect on DER in manufacturing companies listed on the Indonesia Stock Exchange (BEI) for the period 2016 - 2018. According to (Hutabarat, 2013), if the company that produces TATO is higher, the company will show sufficient lots of business volume so that the company can increase the value of sales. According to (Suweta \& Dewi, 2016), the increase in tattoos shows that the performance of management in managing its assets is effective, so that when the turnover of a company's assets increases, the higher its sales. When the level of activity of the company is high, it will reduce the use of its debt. The higher the TATO, the higher the company creates profit from sales, so a high asset turnover will reduce the use of external funds from the risks faced (Noviandini \& Welas, 2017).

The results of this study were in line with the results of research conducted by (Noviandini \& Welas, 2017) that the total asset turnover partially has no effect on the capital structure. This is because when creditors provide long-term loans, creditors do not only see the asset rotation side, but many aspects are considered. The research conducted (Hartiwi et al., 2019) also stated that Total Asset Turnover has no influence on the Capital Structure of the Advertising, Printing and Media sub-sector companies for the 2012-2016 period. This is because the higher the Return on Equity, the better it means that the position of the company owners is getting stronger. Vice versa. If, a company with a high level of Return on Equity will generally use little or no debt.

\section{The Effect of Sales Growth on Capital Structure}

From the partial test results, it can be seen that the Sales Growth variable has a tcount of 1.962 with a t table of $\mathrm{t} d f=173$, it is obtained a t table of 1.97419 . Then tcount $<$ ttable $(1.962<1.97419$ with a significant value of $0.051>0.05$. This shows that partially TATO has no significant effect on DER inmanufacturing companies listed on the Indonesia Stock Exchange (IDX) for the period 2016-2018. Sales growth is a performance companies to gain profits after determining a sales target. According to (Yudiandari, 2018) Companies that have a higher sales growth rate so that the company's dependence on debt will be lower. When sales growth increases, the company will also need high capital to support the company's development. (Halim \& Widanaputra, 2018) Increasing high sales growth in a company tends to increase the use of debt in its capital structure (Suweta \& Dewi, 2016). The results of this study were also in line with the results of research (Naray \& Mananeke, 2015) which stated that growth does not have a significant effect on the capital structure because companies with high sales growth will tend to generate greater cash flow so that the company will use its internal funds. Research conducted (Prihasti, 2018) 
stated that taxes have no effect on capital structure. (Seftianne \& Handayani, 2011) also stated that the business risk variable has no effect on the company's capital structure.

\section{Conclusion}

\section{Conclusion}

Current Ratio partially has a negative and significant effect on the Capital Structure of manufacturing companies listed on the IDX for the period 2016 - 2018, Return on Assets partially has no significant effect on the Capital Structure of manufacturing companies listed on the IDX for the period 2016 - 2018, Total Asset turnover partially does not have a significant effect on the Capital Structure of manufacturing companies listed on the IDX for the 2016 - 2018 period, Sales Growth partially does not significantly affect the capital structure of manufacturing companies listed on the IDX for the 2016 - 2018 period. If simultaneously Current Ratio, Return on Assets, Total Asset Turnover and Sales Growth simultaneously have a significant effect on the Capital Structure of manufacturing companies listed on the IDX for the period 2016 - 2018 with a determination coefficient of $50.2 \%$,

\section{Suggestion}

Based on the results of the study above, the researcher suggests manufacturing companies listed on the Indonesia Stock Exchange to carefully optimize their funding or capital structure and see the level of risk because good and bad capital structure in the company will affect the company's finances. For further researchers, it is necessary to broaden their knowledge and language, to work in groups even more, and to add independent variables and to increase the period of observation.

\section{References}

Akhtar, M. F., Ali, K., \& Sadaqat, S. (2011). Factors influencing the profitability of Islamic banks of Pakistan. International Research Journal of Finance and Economics, 66(66), 125-132. https://doi.org/http://joc.hcc.edu.pk/faculty_publications/IRJFE_66_12.pdf.

Chandra, A., Tantoni, W., Villany, W., Lubis, M. S., \& Akbar, F. (2019). Pengaruh Struktur Aktiva, Return on Assets Dan Pertumbuhan Penjualan Terhadap Struktur Modal Pada Perusahaan Property Dan Real Estate Di Bursa Efek Indonesia Tahun 2011 - 2015. Jurnal Profita, 12(2), 263. https://doi.org/10.22441/profita.2019.v12.02.007

Claude, R. (2016). Capital Structure, Organizational Determinants and Financial Perfomance of Firms Registered in Rwanda Development Board. The International Journal of Business \& Management, $4(8), 105-129$.

Deviani, M. Y., \& Sudjarni, L. K. (2018). Pengaruh Tingkat Pertumbuhan, Struktur Aktiva, Profitabilitas, Dan Likuiditas Terhadap Struktur Modal Perusahaan Pertambangan Di Bei. E-Jurnal Manajemen Universitas Udayana, 7(3), 1222. https://doi.org/10.24843/ejmunud.2018.v7.i03.p04

Dewi, P. D. A., \& Suaryana, I. G. N. A. (2013). Pengaruh EPS, DER, Dan PBV Terhadap Harga Saham. E-Jurnal Akuntansi, $4(1)$, 215-229. https://doi.org/https://ojs.unud.ac.id/index.php/Akuntansi/article/download/5924/4804.

Fahmi, I. (2015). Analisis Laporan Keuangan (D. Handi (ed.)). Alfabeta.

Ghozali, I. (2018). Aplikasi Analisis Multivariate dengan Program IBM SPSS 25. Badan Penerbit Universitas Diponegoro.

Halim, P. M., \& Widanaputra, A. A. G. . (2018). Pengaruh Ukuran Perusahaan, Pertumbuhan Penjualan dan Risiko Bisnis pada Struktur Modal. E-Jurnal Akuntansi, 23(3), 2391. https://doi.org/10.24843/eja.2018.v23.i03.p29

Hartiwi, R. P., Maryanto, T. N., \& Mufidah, A. (2019). Pengaruh Current Ratio, Return On Equity Dan Total Asset Turnover Terhadap Struktur Modal Pada Perusahaan Publik Sub Sektor Advertising, Printing Dan Media Periode. Syntax, 1(8). https://doi.org/https://doi.org/10.36418/syntax-idea.v1i8.103

Haryanto, S. (2016). Profitability Identification of National Banking Through Credit, Capital, Capital Structure, Efficiency, and Risk Level. Jurnal Dinamika Manajemen, 7(1), 11-21. https://doi.org/10.15294/jdm.v7i1.5749

Hery. (2016). Analisis Laporan Keuangan (A. Pramono (ed.)). 
Hutabarat, S. (2013). Pengaruh Rasio Likuiditas, Solvabilitas, Aktivitas, Profitabilitas Dan Rasio Pasar Terhadap Perubahan Laba. MIX, 3(2), 198-210. https://doi.org/10.1017/CB09781107415324.004

Juliantika, N., \& Dewi, M. (2016). Pengaruh Profitabilitas, Ukuran Perusahaan, Likuiditas, Dan Risiko Bisnis Terhadap Struktur Modal Pada Perusahaan Property Dan Realestate. E-Jurnal Akuntansi Universitas $\begin{array}{lll}\text { Udayana, } & \text { 4(7), 4161-4192. }\end{array}$ https://doi.org/https://ojs.unud.ac.id/index.php/Manajemen/article/download/20968/14273

Kesuma, I. K. W., \& Gunadi, G. G. (2015). Pengaruh ROA, DER , EPS terhadap Return Saham Perusahaan Food and Beverages BEI. E-Jurnal Manajemen Unud, 4(6), 1636-1647. https://doi.org/https://repositori.unud.ac.id/protected/storage/upload/repositori/61c27b94c259 5df040a12e4d568017d3.pdf.

Lasut, S. J., Van Rate, P., \& Raintung, M. C. (2018). Pengaruh ukuran perusahaan, profitabilitas, dan likuiditas terhadap struktur modal pada Perusahaan Otomotif yang terdaftar di Bursa Efek Indonesia periode 2012-2015. Jurnal EMBA: Jurnal Riset Ekonomi, Manajemen, Bisnis Dan Akuntansi. https://doi.org/https://doi.org/10.35794/emba.v6i1.18705

Lilie, L., Michael, M., Pramitha, T., Angela, M., Tiffany, A., \& Hwee, T. S. (2019). Pengaruh Earning Per Share, Current Ratio, Struktur Modal, Return on Equity Terhadap Harga Saham Pada Perusahaan Consumer Goods Yang Terdaftar Di Bursa Efek Indonesia. Jurnal Profita, 12(3), 488-503. https://doi.org/10.22441/profita.2019.v12.03.010

Mahirun, \& Kushermanto, A. (2018). Capital Structure, Investment Opportunity Set, Growth Sales, Firm Size and Firm Value: R\&D Intensity as Mediating. Journal of Management System, 19(164), 117-121. https://doi.org/https://www.academia.edu/download/59273352/QAS_Vol.19_No.164_June201820190516-16804-1had32s.pdf\#page=80.

Murhadi, W. R. (2015). Analisis Laporan Keuangan, Proyeksi dan Evaluasi Saham. Salemba Empat.

Naibaho, A., Topowijono, \& Azizah, D. F. (2015). Pengaruh Profitabilitas, Pertumbuhan Penjualan, Struktur Aktiva dan Ukuran Perusahaan terhadap Struktur Modal. Jurnal Administrasi Bisnis (JAB), Vol. 28(1), No. https://doi.org/http://administrasibisnis.studentjournal.ub.ac.id/index.php/jab/article/view/1138

Naray, A. R., \& Mananeke, L. (2015). Pengaruh Pertumbuhan Penjualan, Struktur Aktiva Dan Ukuran Penjualan Terhadap Struktur Modal Pada Bank Pemerintah Kategori Buku 4. Jurnal EMBA, 3(2), 896-906. https://doi.org/ISSN 2303-1174

Noviandini, \& Welas. (2017). PENGARUH CURRENT RATIO, RETURN ON ASSET DAN TOTAL ASSET TURN OVER TERHADAP STRUKTUR MODAL PADA PERUSAHAAN PUBLIK SUB SEKTOR MAKANAN DAN MINUMAN PERIODE 2011-2015. Akuntansi Dan Keuangan, 6(1). https://doi.org/http://journal.budiluhur.ac.id/index.php/akeu/article/view/348

Pradana, H. R., \& Kiswanto, F. (2013). Pengaruh Risiko Bisnis, Struktur Aset, Ukuran Dan Pertumbuhan Penjualan Terhadap Struktur Modal. Accounting Analysis Journal, 2(4), 423-429. https://doi.org/10.15294/aaj.v2i4.4168

Premawati, I. G. A. S., \& Darma, G. S. (2019). Pengaruh Ukuran Perusahaan, Pertumbuhan Penjualan, Struktur Aktiva, dan Profitabilitas Terhadap Struktur Modal (Penelitian Di Bursa Efek Indonesia Periode 2011-2015). Jurnal Ilmiah Akuntansi Dan Bisnis, 2(2), 272-286. https://doi.org/http://dx.doi.org/10.38043/jiab.v2i2.2077

Prihasti, P. R. (2018). Faktor-faktor yang mempengaruhi struktur modal perusahaan manufaktur di Bursa Efek Indonesia. Jurnal Ilmu Dan Riset Akuntansi (JIRA), 7(2). https://doi.org/http://jurnalmahasiswa.stiesia.ac.id/index.php/jira/article/download/61/76.

Riyanti, \& Darto. (2019). The Effect of Liquidity, Profitability and Size Ratios on Capital Structure and Implications for the Value of Manufacturing Industry Companies Listed on the IDX. KnE Social Sciences, 2019, 849-871. https://doi.org/10.18502/kss.v3i26.5419

Seftianne, S., \& Handayani, R. (2011). Faktor-faktor yang mempengaruhi struktur modal pada perusahaan publik sektor manufaktur. Jurnal Bisnis Dan Akuntansi, 13(1), 39-56. https://doi.org/https://doi.org/10.34208/jba.v13i1.214

Setia Rini, R., Puspitaningtyas, Z., \& Prakoso, A. (2018). Pengaruh Current Ratio, Total Asset Turnover Dan 
Debt To Equity Ratio Terhadap Price To Book Value Dengan Return On Asset Sebagai Variabel Intervening (Studi Pada Perusahaan Sektor Industri Barang Konsumsi di Bursa Efek Indonesia Periode 2013-2017). Jurnal Profita, 329-358. https://doi.org/10.22441/profita.2018.v11.03.001

Siregar, H. (2018). Analisis Struktur Aktiva, Net Profit Margin, Dan Current Ratio Terhadap Capital Structure Pada Perusahaan Go Publik Di Bursa Efek Indonesia. Jurnal Manajemen Bisnis STIE IBBI, 30(1). https://doi.org/10.31219/osf.io/smc56

Supardi, H., H. Suratno, H. S., \& Suyanto, S. (2016). Pengaruh Current Ratio, Debt To Asset Ratio, Total Asset Turnover Dan Inflasi Terhadap Return on Asset. JIAFE (Jurnal Ilmiah Akuntansi Fakultas Ekonomi), 2(2), 16-27. https://doi.org/10.34204/jiafe.v2i2.541

Suweta, N., \& Dewi, M. (2016). Pengaruh Pertumbuhan Penjualan, Struktur Aktiva, Dan Pertumbuhan Aktiva Terhadap Struktur Modal. E-Jurnal Manajemen, https://doi.org/https://ojs.unud.ac.id/index.php/Manajemen/article/view/21063

Tanri, J., Behrry, F. Z., Vandana, L., Winarno, I. M., \& Afiezan, A. (2020). Pengaruh Current Ratio, Net Profit Margin, Stabilitas Penjualan dan Struktur Aktiva terhadap Struktur Modal di BEI Periode 2014-2017. Owner, 4(1), 227. https://doi.org/10.33395/owner.v4i1.189

Watiningsih, F. (2018). Pengaruh Profitabilitas, Ukuran Perusahaan, Tangibility, Dan Pertumbuhan Terhadap Struktur Modal Pada Perbankan Yang Terdaftar Di Bei Periode 2008-2016. Jurnal SEKURITAS (Saham, Ekonomi, Keuangan Dan Investasi), 1(4), 92-105. https://doi.org/10.32493/skt.v1i4.1382

Watung, A. K. S. (2016). Pengaruh Rasio Likuiditas, Aktivitas, Profitabilitas, Dan Struktur Aktiva Terhadap Struktur Modal Industri Barang Konsumsi Di Bursa Efek Indonesia. Jurnal EMBA: Jurnal Riset Ekonomi, Manajemen, Bisnis Dan Akuntansi, https://doi.org/https://doi.org/10.35794/emba.v4i2.13152

Widhiari, N., \& Aryani Merkusiwati, N. (2015). Pengaruh Rasio Likuiditas, Leverage, Operating Capacity, Dan Sales Growth Terhadap Financial Distress. E-Jurnal Akuntansi, 11(2), 456-469. https://doi.org/https://repositori.unud.ac.id/protected/storage/upload/repositori/70a4dd27b6f0 237aeef9e0667a9ae426.pdf.

Wijayanto, A. (2010). Analisis Pengaruh Roa, Eps, Financial Leverage, Proceed Terhadap Initial Return. Jurnal Dinamika Manajemen, 1(1), 68-78. https://doi.org/10.15294/jdm.v1i1.2451

Yudiandari, C. I. D. (2018). Pengaruh Profitabilitas, Operating Leverage, Ukuran Perusahaan dan Pertumbuhan Penjualan pada Struktur Modal. E-Jurnal Akuntansi Universitas Udayana, 22(1), 408437. https://doi.org/10.24843/EJA.2018.v22.i01.p16 